
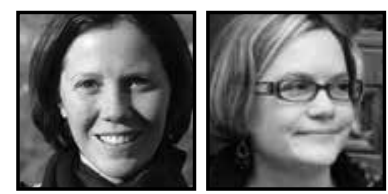

\title{
Listening to Children's Voices: Reflections on Researching With Children in Multilingual Montreal
}

\author{
Alison Crump and Heather Phipps, McGill University
}

\begin{abstract}
In this paper, we discuss methodological and ethical issues related to researching with children in a way that respects and validates their voices. Drawing on vignettes from one of the author's inquiries with young multilingual children, we share strategies we see as central to positioning children as knowledgeable and active agents in their own and our learning. We propose three main criteria for doing qualitative research with children: fostering respectful relationships; using creative methods; and listening attentively to children's stories. We discuss what these criteria can contribute to early childhood education, both in formal and non-formal settings.
\end{abstract}

esearching with children involves actively listening to their voices and vali-
dating their stories; working with young children can open spaces for mean-
ingful, respectful, and inclusive engagements in learning in both formal and non-formal educational settings. Yet, the insights and ideas of young children are too often overlooked as important and valid contributions to understandings of issues that directly affect the children themselves (Howe \& Covell, 2005; Lewis, 2004). In this paper, we hope to contribute to a movement that challenges this silencing of children and to emphasize the importance of doing research with children, not about them (e.g., Fraser, Lewis, Ding, Kellet, \& Robinson, 2004; Graue \& Walsh, 1998; Maguire, 2005; James $\&$ Prout, 1997). As doctoral student researchers working with qualitative methodologies in our research with children, we shed light on the importance and value of listening to and affirming the voices and knowledges of children. We argue that qualitative research is enriched when the voices of children are respected, valued, and encouraged. 
We share strategies we see as central to positioning children as knowledgeable and active agents in their own and our learning and show how much we learned from children when we used these strategies. We conclude with a discussion of what these learnings can contribute to early childhood education, both in formal and non-formal settings.

\section{Setting the Scene}

The context of our inquiries is multilingual Montreal. Montreal is the largest city in the province of Quebec and it receives and integrates over $85 \%$ of the immigrants to the province (Statistics Canada, 2006). Though Canada is officially bilingual at the federal level, since 1977, with the enactment of Bill 101, French has been the sole official language in Quebec. Bill 101 mandates that children of immigrants be educated in French and there are strict rules regarding who qualifies for a Certificate of Eligibility, which is required for admission to English schools; as a result, over $90 \%$ of children in Quebec are now educated in the French sector (Sarkar \& Winer, 2006). Though Bill 101 aims to protect French language and culture, an inadvertent effect of this language policy, at least in the multiethnic metropolis of Montreal, has been the increase of multilingualism (Lamarre \& Dagenais, 2004). In fact, Montreal is the city in North America with the highest number of trilinguals (Lamarre, 2003) and the rate of multilingualism seems to be increasing. For example, almost $80 \%$ of children in Quebec attend daycares, many of them in languages other than those they speak at home (Perreault, 2002; Poliakova, 2002).

Multilingual children in Montreal take their multilingual language resources with them when they enter formal education contexts. Despite the increasing linguistic diversity classrooms, educational policies and practices remain, for the most part, stubbornly founded on monolingual ideology (Blackledge \& Creese, 2010; Cook, 2001; Cummins, 2009; García, 2009; Hélot, 2007), which is the idea that languages need to be kept separate in order for learning to take place. This ideology affects multilingual children directly by constricting spaces for them to draw on their language resources in their learning. This has implications for how children come to see themselves and others.

Our inquiries are located in this context and we are exploring how multilingual and multiethnic children are navigating the linguistic landscape of Montreal. However, we feel that the criteria we propose in this paper would resonate in other educational contexts as well. With this background in mind, we shift the discussion to key 
methodological issues in researching with children in a way that respects and validates their voices. We begin by locating our thinking in what James and Prout (1997) called the "new sociology of childhood."

\section{Child-Centered Qualitative Research}

Child-centered research focuses on actively involving children in the research process and is primarily concerned with questions and issues that are of importance to the lives of children and young people. The research process must be meaningful to children. In other words, researchers must think about the relationships they build with child participants, how they communicate and build trust, and how the process may provide children with the opportunity to demonstrate their knowledge and competencies.

With the rise of the new sociology of childhood, children are increasingly becoming active participants in qualitative research processes. We agree with Christensen and James (2008), however, that much of the research that is "avowedly child-focused" does "little to enable us to learn from children's own perspectives on their everyday lives and experiences" (p. 1). We take seriously Strong-Wilson and Preece's (2009) statement regarding "the importance of creating shared spaces for dialogue between adults and children. It is in these spaces that some of the stories most meaningful to children and childhood will grow" (pp. 4-5). How may we better understand the ways in which children develop agency through their interactions with peers and adults in a linguistically and culturally diverse context, such as Montreal? We seek to understand the interests of children and to engage them in meaningful, enriching experiences. By listening attentively to children's voices and engaging children as co-researchers, we hope to understand more about their complex, dynamic, and multi-faceted social worlds. As Geertz (1986) wrote, "We cannot live other people's lives, and it is a piece of bad faith to try. We can but listen to what. . . they say about their lives" (p. 373). This points to the critical question of how to approach doing research with children and ensuring that children's voices are heard and acknowledged.

When children's voices are silenced or overlooked, this reinforces beliefs that children are inferior beings whose opinions are not worthy of including in research (Howe \& Covell, 2005). There is value in gathering and documenting adults' perspectives, yet there is also a danger of interpreting such data as representative of children's own understandings and meanings (Van Ausdale \& Feagin, 2001). Janzen (2008) called for more childhood research that provides opportunities and spaces for children to 
co-construct knowledge, cultures, and identities. What we learn from researching with children can impact the lives of the children we're working with, but also others in similar situations. Young children can highlight what is salient to them and can complement and sometimes contradict adult perspectives (Nutbrown \& Hannon, 2003; Waller, 2006). By approaching children as knowledgeable, we are positioning ourselves as people who want to learn from them, who are genuinely interested in what they say and do (Christensen \& James, 2008). This reflects what Graue and Walsh (1998) called the "humble researcher position."

We now turn to discussing some vignettes from Alison's inquiry with four multilingual Japanese-Canadian children in Montreal which illustrate how she has tried to take a humble researcher position and some of the strategies she has used to co-create conditions for children to voice their experiences and share their stories.

\section{Introducing the Children}

Over a period of six months, Alison visited four Japanese-Canadian children at their homes with the aim of understanding how they make sense of their multilingualism. The home visits were all audio-recorded on two digital voice recorders (one often became a toy). The children are': Henry (age 6) and Elizabeth (age 4), who are brother and sister. They speak Japanese, English, and French. James (age 4) speaks Japanese and English. He knows he will learn French when he starts school next year, like his older brother has. Taichi (age 4) speaks Japanese, English, and French.

\section{Conversations with Children}

Children make sense of their feelings, emotions, memories, identities, and experiences through stories. As child psychologist Susan Engel (1995) wrote, "It is through telling stories that children develop a personal voice, a way of communicating their unique experience and view of the world" (p. 2). Thus, in order to welcome children's voices, in our methodological approaches we have deliberately avoided an interview approach and aimed instead to co-create conditions for conversations with the children. Maguire (1999) found that " $[c]$ onversations with children in informal settings rather than structured interviews are more useful ways to gain insights into children's lives, their understandings of their situations, [and] their cultural identities" (p. 131). In addition, James (2001) argued that especially when doing research with children in their homes, where they are positioned as relatively powerless in relation to their parents, engaging in informal conversations with the children, rather than conducting formal interviews, gives them more control over the flow of the dialogue. As we show in the vignettes 
that follow, creating the conditions for conversations with children can open spaces for children to voice their stories, which can help us gain a deeper understanding of their perspectives on issues that relate directly to their lives. Here we illustrate the strategies we feel are central to listening to and engaging with children.

\section{Respecting}

Respecting the children's spaces and interests is central to shaping the inquiry and to creating spaces for conversations that are led just as much by the children as by the adult researcher. As Alison learned, though it is tempting to arrive for the home visits with an agenda of what she wanted to get out of the interactions, respecting means that any agenda had to be co-constructed and negotiated.

Though easy enough to say, negotiating an agenda in the moment of interaction can be harder to do. We share here an example of a moment when Alison was finding it hard to let go of her expectations. At the end of her first visit with Taichi (age 4), he told her that he wanted to do some drawing next time, so the next time, she brought a stocked craft bag, fully expecting to spend this home visit drawing with him. Clearly, he had other ideas.

Alison: Do you want to see what I brought with me today?

Taichi: What did you brought?

Alison: I brought stuff for colouring. Do you like colouring? I've got pencil crayons, crayons, markers, paper.

Taichi: I have paper here. [He doesn't want mine].

Alison: I brought a picture of a person. [I show him a paper with the outline of a person].

Taichi: I don't want a picture of a person.

Alison: Okay. . .l brought some folders. Do you know what these are? [I take plastic folders out of my bag].

Taichi: What's inside them?

Alison: Nothing, but you could put your drawings in them and then it would be like a book. [He picks up my box of markers]. Do you want to open them?

Taichi: I don't want to open them. 
Alison: No. Do you want me to open them?

Taichi: $\quad$ No.

Alison: Well I'll leave these here if you want to do some drawing. Can I draw a picture for you?

Taichi: I don't want pictures.

Alison: No pictures.

[Taichi runs out of the living room to his room and returns a minute later with a train set puzzle from Japan. We put the track together and play trains for a long time].

As a researcher, letting go of the power to direct interactions is not always as easy to actually do as it is to write about doing. Indeed, Maguire (2005) noted that she rarely saw researchers writing about how children challenged or resisted their agendas. However, Alison found that the children have very explicit ways of resisting her agenda (e.g., by physically leave the room), if she tried to impose one. When she is in the children's homes, she is on their turf and they want to be largely in charge of the interactions. And as a humble researcher, Alison has done her best to respect that and let the children lead the negotiations of the rules of play.

Respecting involves letting go of power and control; it involves listening, being nondirective, and being humble in the homes and spaces of the children we are working with. Within this climate of respect, there are several types of activities Alison engaged in with the children, which have been very productive for generating data. ${ }^{2}$ These are discussed below.

\section{Drawing}

Vygotsky (1978) argued that children's drawings are representations of story. Drawings can serve as a productive tool to engage children in conversations about their visual representations (Kendrick \& McKay, 2004; Kendrick, McKay, \& Moffat, 2005). We would like to emphasize the importance of paying close attention to the conversations that take place while the drawing is being created since this is when meaning is emerging and being co-created. As Roberts-Holmes (2005) noted, once a drawing is done, young children will not often have much to say about it. As Alison found in her inquiry, talk around drawings is meaningful only in the moment, but after the drawing is done and the children have moved on to the next activity (e.g., a giant tickle fight), the conversations about the drawing are minimal to none. In addition, drawings 
do not need to be done by the children alone. In fact, collaborative drawings led to very rich conversations.

Alison arrived for each visit with a craft bag, stocked with slightly different things, but always copies of a paper with the outline of a person on it. The idea was to ask the children to colour in the person, using a different colour pen for each language they speak, and that this would be a nice way to elicit conversations about their understandings of their multilingualism. In practice, this never happened, but the collaborative drawing Henry (age 6), Elizabeth (age 4), and Alison did on the person outline ended up creating the conditions for a very rich conversation about their language practices. The drawing became very multi-layered; as they drew, a co-created story emerged.

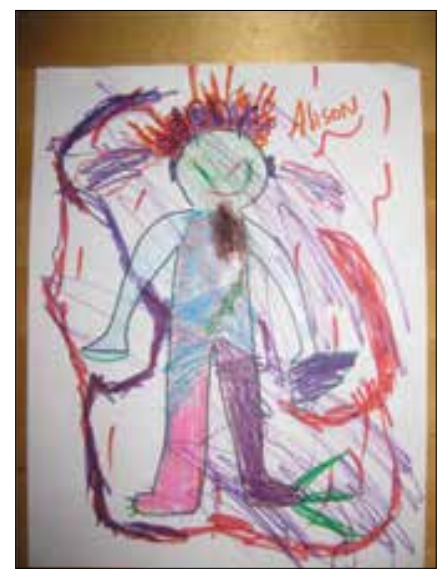

Fig. 1: Collaborative drawing

Alison: So, let's see. I speak English, French, and a bit of Japanese and a little bit of Spanish [as I say this, I pick up a different colour marker for each language].... Because I speak only a little bit of Spanish, I'm just going to make purple ears. Just a little bit.

Henry: And what about English? You speak English...

Alison: I speak mostly English [I am colouring the body with red for English]. Which part do you think I should do? How far should I go?

Henry: Maybe like that. [He points at the knees, so I stop the red the knees. Elizabeth is watching, and colouring in her own person with 
purple stripes]. ... French, you could go for the face. ... Elizabeth speaks Japanese the most. [She nods]. I speak English, then Japanese.

Alison: And what about French?

Henry: Yeah, and Spanish.

Alison: Yeah, English the most and then Japanese?

Henry: $\quad$ Then French, then Spanish. A bit of Spanish. Maybe I could do two ears like you.

Alison: Two ears of Spanish. ... Do you ever speak in French when you do activities? Or just at school?

Henry: Just at school. Sometimes when I have a friend come over.

Alison: What about when you go shopping to the store, do you speak French?

Henry: To who?

Alison: To the people in the store. Do they speak French?

Henry: If they speak French to me, I speak French to them.

Doing this collaborative drawing created spaces for Henry to share his understandings of his and his sister's multilingualism.

\section{Reading Stories}

During Alison's first home visit with Taichi (age 4), he was really excited and wanted to show her all of his favourite toy cars and trucks and his big stuffed Totoro (a popular Japanese animation character). At first, Totoro was something to throw at the wall. But, when Taichi started jumping on his bed, Totoro became a character in play and told Taichi that he wanted to settle down a bit and read a book together.

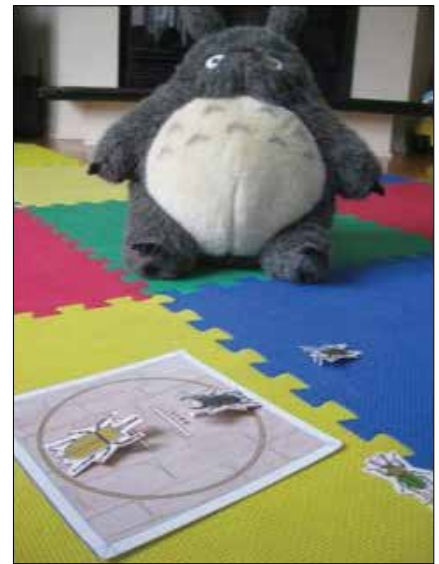

Fig. 2: Totoro joins the conversation 
Totoro picked a Japanese book to read. Fushigi Hakken Ehon is a picture book about two types of insects.

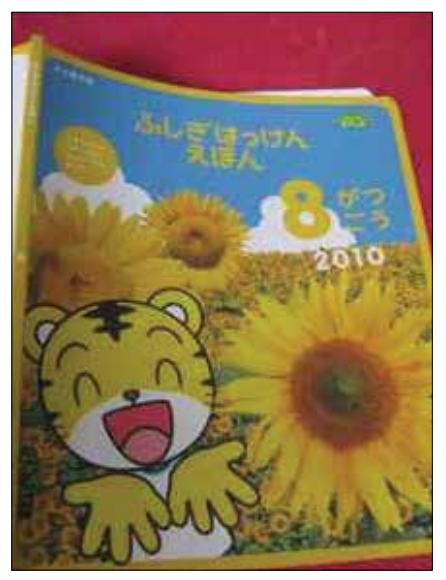

Fig. 3: Fushigi Hakken Ehon

Though it was hard for Alison to read the book in Japanese, doing so created opportunities for negotiation of meaning and for Taichi to correct her pronunciation. In doing this, Taichi got to position himself as a competent Japanese speaker.

Alison: What's this?

Taichi: $\quad$ Mitsu. Mitsu.

Alison: Mitsu? [I am checking my pronunciation. Mitsu means honey or three, depending on how it is pronounced].

Taichi: Mitsu. Mitsu.

Alison: Mitsu?

Taichi: Honey. [He gave up on me getting the Japanese pronunciation right and switches to English to make sure I understand].

Later in the book, there is a page with different insects to count. Interestingly, Taichi counted them in Japanese, likely because this is how he reads the book with his mother. At one point when Alison was reading to him, he said, "Your Japanese is very funny." She had to agree.

During Alison's last visit with Henry (age 6) and Elizabeth (age 4), she brought them a book to thank them for spending time with her. The book, "Suki's Kimono," is written by Chieri Uegaki (2003), a Japanese-Canadian author. It is about a young girl, Suki, who wears her kimono to the first day of grade one. She gets teased, but shares the story of the summer festival she went to with her obaachan (grandmother) in this kimono. 


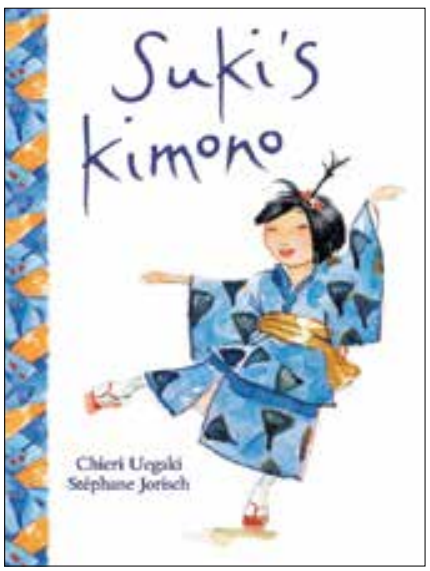

At the end of her story, her classmates loudly applaud her. There is a strong message of accepting differences and being proud of your cultural heritage.

Fig. 4: Suki's Kimono

Cover of Suki's Kimono by Chieri Uegaki, illustrated by Stéphane Jorisch reprinted by permission of Kids Can Press Ltd., Toronto, Canada. Text $\odot 2003$ Chieri Uegaki. Illustrations $\odot 2003$ Stéphane Jorisch.

As soon as Henry and Elizabeth saw the cover of this book, they were captivated. As Alison read, Elizabeth asked more and more questions and responded to Suki's actions with her own (standing up and mimicking Suki's dance). Henry, on the other hand, became very quiet and seemed to be thinking deeply about the story. When Alison finished reading the story, Elizabeth ran to her room to get her kimono. Henry took the book and slowly turned through all the pages and said he liked the book "very much." Elizabeth said she liked the part where all the classmates clapped for Suki.

Reading this book and talking about it seemed to serve as a mirror for these children as they could recognize parts of their own lives in the book. The shared reading experience enabled the children and Alison to engage in dialogue and provided the opportunity to playfully enact parts of the story. In the excerpt below, Elizabeth uses her imagination to engage with the story as she listens to Suki's vivid description of her experience of dancing at the festival, barefoot on the grass.

Alison: [I am reading the story]. "Suki took a deep breath and continued. The best thing was that my obaachan took me to a festival. And there were dancing girls, dressed like me, and they danced like this. She took a few steps and swayed her arms sideways" [Elizabeth is moving her arms a bit now]. "Look now she's dancing, someone said. But Suki didn't hear. She hummed the music she remembered hearing at the festival. She remembered how it felt to dance barefoot in the open air, on fresh-cut grass that tickled her toes." 
[Elizabeth is standing up now, with her hands in the air, just like picture of Suki, her toes wiggling]. "She tried to picture the other dancers. How they moved forward in a circle."

Elizabeth: It doesn't tickle.

Alison: Well, there's no grass under your toes, is there? "They stamped their feet, first right, then left, swung their arms, first up, then down. How they stepped back and back and back, then clapped."

Elizabeth: Now it tickles. Now it tickles! [She has taken off her socks and is wiggling her toes in the shag rug.]

Alison: Does it tickle? "When Suki couldn't remember the next step, she just made it up, just to keep on dancing. 1-2, 1-2, 1-2, stop." She made up her own dance. "When she finished, the room seemed very quiet. Everyone was watching her."

An important part of these shared reading experiences from storybooks are the social interactions and dialogue that occurred throughout. The stories provided an interesting point of discussion for Alison and the children, as the children related their own knowledge and prior experience to the visual images and words of the stories. While reading the stories, Alison tried to listen attentively to the questions and comments made by the children and they seemed eager to share their thoughts and opinions.

\section{Playing}

Vivian Paley, preschool and kindergarten teacher and writer, has described the centrality of play and stories to children's lives. In The Girl With the Brown Crayon: How Children Use Stories to Shape their Lives, Paley (1997) portrayed the remarkable way in which children related their own lives to the stories they read and how the texts became a springboard for discussion about complex issues such as gender equity and race, as well as their emotions and relationships. Playing with children and providing spaces for children to play is a critical part of creating conditions in which children can share their voices and their stories. Play was the primary method of generating data with the children in Alison's inquiry. There are endless ways to play and children all have their own favourite games to play or ways to play. Here, we illustrate how engaging in play that is largely led by the children creates spaces for meaningful conversations with them. 


\section{Playing with toys.}
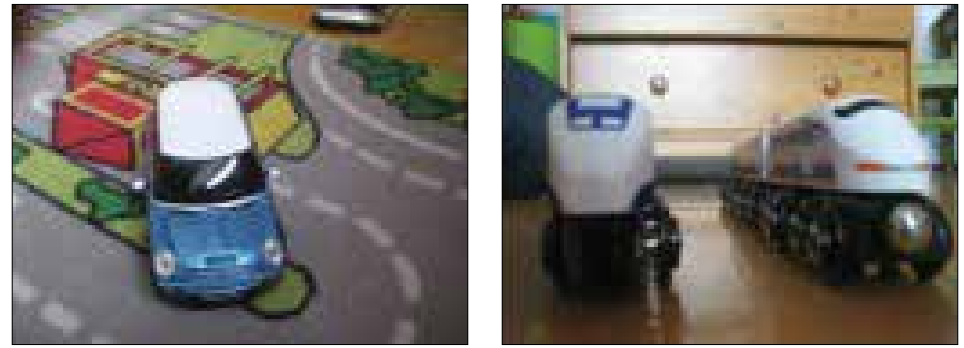

Fig. 5: Props for "Canada and Japan"

For a couple of weeks, James (age 4) and Alison played a game he came up with called "Canada and Japan," where the carpet in his room was Canada and the train track was Japan. They would drive around to shops and gas stations and parking lots, and amid lots of "vroom vroom" driving sounds, every now and then, they would comment on what they might hear people saying in those places.

Alison: And when you go shopping, do you hear people speak French?

James: Yup, and English and Japanese.

Alison: And Japanese? Do you think everyone speaks Japanese?

James: Yeah.

Alison: Everyone, everyone in Montreal, in Canada?

James: In Canada, they speak only English.

Alison: Only English.

James: Yeah.

Alison: What about in Montreal?

James: Yup.

Alison: Only English?

James: In Montreal? Yes.

Alison: And where do people speak Japanese?

James: In Japanese school.

Alison: And Japan? 
James: $\quad$ Yeah. That's where Baba and Jiji (Grandma and Grandpa) live. Can you draw this? [He wants me to finish colouring a car. He has had enough of my language questions.]

Through imaginative play with James, he demonstrated a strong bilingual and multi-ethnic identity and a keen awareness of how different languages "fit" in different places, though he is still working out explaining where they fit. We are sure that it would have been difficult to access this type of knowledge directly through an interview-type approach.

\section{Playing games.}

None of the conversations with the children took place in isolation from other activities; there was always something going on behind the scenes of the conversations. Activities give children something to focus on. They also help avoid the temptation, as an adult researcher, to fall into a question-and-answer interview-type interaction (Roberts-Holmes, 2005).

The first time Alison visited Henry and Elizabeth, they had just borrowed a board game from a friend, called "City Square Off." They were excited about the game and wanted to play it. They sat down in the hallway and started to play the game, so Alison joined them. As they played, they chatted. Attention was mostly focused on the game (e.g., negotiating turns, reflecting on moves, predicting later moves), but conversation flowed easily to other things.

Alison: Does anyone else at your school speak Japanese?

Elizabeth: Um, yes. But my Japanese girl goed somewhere.

Alison: Where did she go?

Elizabeth: Vancouver.

Alison: That's far away.

Henry: There's one in grade seven. I know him. His name is Ryu-kun.

Alison: And he's Japanese?

Henry: $\quad$ Yes. His mom is from Japan. He speaks the same languages as us.

Alison: The same three. French and English and Japanese. So when you see him, what language do you talk to him in?

Henry: $\quad$ Any language.

Elizabeth: And the Vancouver one too. 
Alison: You speak to her in any language or in Japanese.

Elizabeth: Japanese and English and French.... I speak a lot of Japanese.

Henry: Okay, put it down. [Henry is bringing attention back to the game and telling me to put my block on the board.]

Clearly, what we have shared here only represent a fraction of the many and varied ways to play with children. We have chosen these particular vignettes because they illustrate the dynamic, active, negotiated process of generating data with young children. We would like to highlight one more very important element of doing research with children: being playful.

\section{Playfulness}

When Alison first visited the children in their homes, there was always some negotiation of expectations on everyone's behalf. The children were trying to figure out what kind of adult she was; the mothers were trying to figure out whether to be in the room or elsewhere (they soon realized they could use the time to do something else). Alison was trying to figure out what the children were interested in. A great way to break this ice and start to sort out some of this negotiation of expectations is to be silly and playful with the children.

We share one of many examples of giggles Alison shared with the children. In her first visit with James he asked her to draw him some pictures of his favourite toy car, which he coloured in and cut out. They were sitting on the floor, his box of washable Crayola markers in between them.

James: $\quad$ See the bubbles here? That means sky blue. [Washable markers all have bubbles on them].

Alison: Wait a second. [l pick up a yellow marker]. This has bubbles on it too. That's not sky blue.

James: Why?

Alison: It's yellow. Is it sky yellow?

James: No [laughs].

Alison: [I pick up a purple marker]. Sky purple?

James: Yeah [laughs].

Alison: [l pick up a green marker]. Sky green? 
James: [Giggles].

Alison: That's too silly! [I pick up a pink marker. We make eye contact]. Sky, James/Alison: Pink! [We laugh. I pick up a red marker].

Alison: Sky, [We pause and make eye contact to get the timing right]. James /Alison: Red! [More laughter].

Alison: Now what are we going to draw? [I think the game is over].

James: Sky. Do this one. [The game is not over].

Alison: What this one? Sky,

James: Black! [We laugh].

Alison: What else? Are there more?

James: Yeah there are. Purple. [This goes on until James decides the game is over].

Moments like these were just as important in Alison's inquiry as the ones where the children were talking about their understandings of multilingualism. Being playful with the children helped build a rapport with them; as such, it is an essential ingredient for generating data with young children.

\section{Learnings for Early Childhood Education}

Child-centered research involves considering the interests and strengths of children in order to ensure that children actively participate in ways that are meaningful to their own lives. In this paper, we have provided examples of how children express their thoughts and ideas through conversations, responding to stories, drawings, and through play. From our discussion, we have drawn three criteria that we believe are essential for researching with young children, as well as for working with children in various early childhood contexts.

\section{Respectful relationships}

Maori scholar Mere Berryman (2012) emphasized how important it is "to establish respectful relationships [- it] is central to both human dignity and the research." Having respect for children and caring about issues that are important to them is central to 
researching with children. Researching with children requires self-reflexivity, an awareness of ones' own values and interests, as well as being open to the ideas and perspectives of children. Alison showed how being respectful of children's wishes can sometimes be at odds with the researcher's own agenda, which highlights how critical it is for respectful relationships that the agenda be negotiated and co-constructed. We are guided by Vivian Paley (1986), who wrote that, "When we are curious about a child's words and our responses to those words, the child feels respected. The child is respected" (p. 127). A key to establishing respectful relationships with children is to listen to them closely and to be genuinely open to their thoughts and ideas, and acknowledging their life experiences. Doing qualitative research with children requires time to come to understand their interests and to build a relationship and a rapport with them.

\section{Creative methods}

In this paper, we have shared some examples of creative methods that opened spaces for children to express themselves and share their experiences and stories. These included drawing, reading stories together, and playing with toys, stuffed animals, or board games. This emphasis on creative methods is in line with the arts-based educational philosophy of Reggio Emilia, which states that children express themselves through many languages. As art educator Sylvia Kind (2010) wrote, “Drawing, painting (and the use of all languages) are experiences and explorations of life, of the senses, and of meanings" (p. 121). Using creative methods is central to researching with children, particularly in research involving children's voices and stories. It involves a great deal of imagination and playfulness. Of course the methods used should be relevant to the children, and they are often the ones who come up with the methods and decide on the rules of play. It is important as a researcher and as an educator to ensure that children feel they have agency to do this. This opens up spaces for conversations with children, spaces where children's voices are respected and validated.

\section{Listening}

Researchers are beginning to pay more attention to the stories of young children and to the role of children's narratives in constructing their identities, revealing that, "stories and storytelling are vital to children themselves and to their development" (Engel, 1995, p. 3). Educators in Reggio Emilia schools and in the New Zealand Learning Stories project have used stories to document the unique experiences of young children (Berger, 2010; see also Carr \& Lee, 2012). Berger (2010) discussed how educators acknowledge the plurality of their classrooms through "pedagogical narration," which enables children's multiple identities to "emerge in an unexpected and creative 
manner" (p. 71). Pedagogical narration involves collecting and documenting the stories of children through various materials including both texts and images that are then displayed "as a provocation to continue the discussion, reflection, and interpretation of the pedagogical work among teachers, children, parents, and community members" (Berger, 2010, p. 63).

Like childhood researchers Dyson, Engel, Maguire, and Paley, we have found that when we listen to children, they open up and share their stories. By listening attentively, researchers and educators acknowledge the importance of what children have to say. As Engel (1995) wrote, "[c]hildren are often deeply social in the way that they approach the task of constructing stories. They need responsive, engaged, attuned listeners and collaborators in order to go on trying to express and create themselves through their stories" (p. 218). Listening to children means taking the time to get to know them and to building trusting and respectful relationships.

\section{Closing Remarks}

In this paper, we have drawn on some vignettes from Alison's inquiry to illustrate what we feel are three central and intricately related criteria for doing qualitative research with children: developing respectful relationships; using creative methods; and listening attentively. However, we feel that these criteria can guide not only researchers, but also early childhood educators in their engagements with young children in both formal and non-formal educational settings. In our own developing work as researchers in early childhood education, we would like to further explore methodologies that will allow us to work with children, listen to their stories, and validate the multiple ways they express their identities.

\section{Notes}

1. All names are pseudonyms.

2. We prefer, like Graue and Walsh (1998), to speak of generating data rather than collecting data. Whereas the latter seems to suggest that data already exist and are ready to be picked at the researcher's convenience, the former reflects an active, engaged, and negotiated process. 


\section{References}

Berger, I. (2010). Extending the notion of pedagogical narration through Hannah Arendt's political thought. In V. Pacini-Ketchabaw (Ed.), Flows, rhythms, and intensities of early childhood curriculum (pp. 57-76). New York: Peter Lang.

Berryman, M. (2012). Culturally responsive pedagogy. Keynote address presented at the Culturally responsive research and pedagogy symposium, University of Waikato, Hamilton, New Zealand, November 14, 2012.

Blackledge, A., \& Creese, A. (2010). Multilingualism: A critical perspective. London: Continuum.

Carr, M., \& Lee, W. (2012). Learning stories: Constructing learner identities in early education. London: Sage.

Christenson, P., \& James, A. (2008). Research with children: Perspectives and practices (2nd ed.). London: Routledge/Falmer.

Cook, V. (2001). Using the first language in the classroom. Canadian Modern Language Review, 57, 402-423.

Cummins, J. (2009). Multilingualism in the English-language classroom: Pedagogical considerations. Symposium: Imagining multilingual TESOL. TESOL Quarterly, 43(2), 317-321.

Engel, S. (1995). The stories children tell: Making sense of the narratives of childhood. New York: W.H. Freeman and Company.

Fraser, S., Lewis, V., Ding, S., Kellet, M., \& Robinson, C. (Eds.). (2004). Doing research with children and young people. London: Sage.

García, O. (2009). Education, multilingualism and translanguaging in the 21st century. In A. Mohanty, M. Panda, R. Phillipson, \& T. Skutnabb-Kangas (Eds.), Multilingual education for social justice: Globalising the local (pp. 140-158). New Delhi: Orient Blackswan.

Geertz, C. (1986). Making experience, authoring selves. In V. W. Turner \& E. M. Bruner (Eds.), The anthropology of experience (pp. 373-380). Urbana: University of Illinois Press.
Graue, M. E., \& Walsh, D. J. (1998). Studying children in context: Theories, methods, and ethics. London: Sage.

Hélot, C. (2007). Du bilinguisme en famille au plurilinguise à l'école. Paris: L'Harmattan.

Howe, R. B., \& Covell, K. (2005). Empowering children: Children's rights education as a pathway to citizenship. Toronto: Toronto University Press.

James, A. (2001). Ethnography in the study of children and childhood. In P. Atkinson, A. Coffey, S. Delamont, J. Lofland, \& L. Lofland (Eds.), Handbook of Ethnography (pp. 246257). London: Sage.

James, A., \& Prout, A. (Eds.). (1997). Constructing and reconstructing childhood: Contemporary issues in the sociological study of childhood (2nd ed.). London: Falmer Press.

Janzen, M. (2008). Where is the (postmodern) child in early childhood education research? Early Years, 28(3), 287-298. doi:10.1080/09575140802393827

Kendrick, M., \& McKay, R. (2004). Drawings as an alternative way of understanding young children's constructions of literacy. Journal of Early Childhood Literacy, 4(1), 109-128. doi:10.1177/1468798404041458

Kendrick, M., Mckay, R., \& Moffatt, L. (2005). The portrayal of self in children's drawings of home, school, and community literacies. In M. Kendrick, T. Rogers, \& S. Smythe (Eds.), Portraits of literacy across families, communities, and schools: Intersections and tensions (pp. 185-204). Mahwah, NJ: Lawrence Erlbaum.

Kind, S. (2010). Art Encounters: Movements in the Visual Arts in Early Childhood Education. In V. Pacini-Ketchabaw (Ed.) (2010), Flows, rhythms, \& intensities of early childhood curriculum (pp. 113-132). New York: Peter Lang.

Lamarre, P. (2003). Growing up trilingual in Montreal: Perceptions of college students. In R. Bayley \& S. Schecter (Eds.), Language socialization in bilingual and multilingual societies (pp. 62-80). Clevedon: Multilingual Matters. 
Lamarre, P., \& Dagenais, D. (2004). Language socialization in bilingual and multilingual societies. In C. Hoffman \& J. Ytsma (Eds.), Trilingualism in family, school and community (pp. 53-74). Clevedon: Multilingual Matters.

Lewis, V. (2004). Doing research with children and young people: An introduction. In S. Fraser, V. Lewis, S. Ding, M. Kellet, \& C. Robinson (Eds.), Doing research with children and young people (pp. 1-11). London: Sage.

Maguire, M. H. (1999). A bilingual child's choices, and voices: Lessons in noticing, listening, and understanding. In E. Franklin (Ed.), Reading and writing in more than one language (pp. 116-140). Arlington, VA: TESOL.

Maguire, M. H. (2005). What if you talked to me? I could be interesting! Ethical research considerations in engaging with bilingual/ $\mathrm{mul}$ tilingual child participants in human inquiry. Forum: Qualitative Social Research, 6(1).

Nutbrown, C., \& Hannon, P. (2003). Children's perspectives on family literacy: Methodological issues, findings and implications. Journal of Early Childhood Literacy, 3(2), 115-145. doi:10.1177/14687984030032001

Paley, V. (1986). On listening to what children say. Harvard Educational Review, 56, 2, 122-131.

Paley, V. (1997). The girl with the brown crayon: How children use stories to shape their lives. Cambridge, MA: Harvard University Press.

Perreault, M. (2002). Francophone families turn to English daycare. Series: Bilingualism? Pas de problème. The Gazette, p. A1. Montreal.

Poliakova, E. (2002). L'attitude des parents envers le maintien de langue d'origine: étude de cas auprès trois familles de la communauté russe de Montréal. Université de Montréal.
Roberts-Holmes, G. (2005). Doing your early years research project: A step-by-step guide. London: Sage.

Sarkar, M., \& Winer, L. (2006). Multilingual Codeswitching in Quebec Rap: Poetry, Pragmatics and Performativity. International Journal of Multilingualism, 3(3), 173-192. doi:10.2167/ijm030.0

Statistics Canada (2006). Immigrant status and period of immigration. Retrieved from http://www12.statcan.gc.ca/census-recen sement/2006/dp-pd/hlt/97-557/T403-eng. $\mathrm{cfm}$ ? Lang $=\mathrm{E} \& \mathrm{~T}=403 \& \mathrm{GH}=6 \& \mathrm{GF}=24 \& \mathrm{G} 5=0 \&$ $\mathrm{SC}=1 \& S=0 \& \mathrm{O}=\mathrm{A} \# \mathrm{FN} 3$

Strong-Wilson, T., \& Preece, A. (2009). Editorial: With just a bit of imagination. English Quarterly, 39, 2-5.

Uegaki, C. (2003). Suki's kimono. (S. Jorisch, Illustr.). Toronto: Kids Can Press.

Van Ausdale, D., \& Feagin, J. R. (2001). The first $r$ : How children learn race and racism. Lanham: Rowman \& Littlefield.

Vygotsky, L. (1978). Mind in society. (M. Cole, V. John-Steiner, S. Scribner, \& E. Souberman, Eds.). Cambridge, MA: Harvard University Press.

Waller, T. (2006). "Don't come too close to my octopus tree": Recording and evaluating young children's perspectives on outdoor learning. Children, Youth and Environments, 16(2), 75-104. 


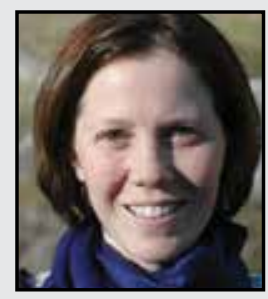

Alison Crump is a PhD candidate in the Department of Integrated Studies in Education at McGill University. She has been doing her doctoral research with Japanese-Canadian children and is trying to understand how they make sense of their multilingual language practices. She is an instructor in the $\mathrm{B}$. Ed TESL and TESL Graduate Certificate programs at McGill.

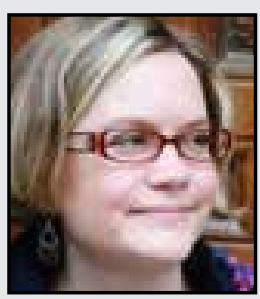

Heather Phipps is a PhD candidate in the Department of Integrated Studies in Education at McGill University. A former Kindergarten and Elementary teacher, Heather is interested in qualitative and ethnographic research methodologies with young children. Heather's doctoral study explores the role of multicultural Canadian stories in children's lives within culturally and linguistically diverse classrooms in Montreal. 